\title{
Sandstone reservoir characteristics of Rio Del Rey basin, Cameroon, using well-logging analysis
}

\author{
Janvier Domra Kana ${ }^{1} \odot$ - Ahmad Diab Ahmad ${ }^{2}$. Daniel Hervé Gouet ${ }^{1} \cdot$ Xavier Djimhoudouel $^{1}$. \\ Serge Parfait Koah Na Lebogo ${ }^{3}$
}

Received: 29 March 2021 / Accepted: 7 June 2021 / Published online: 29 June 2021

(c) The Author(s) 2021

\begin{abstract}
The present work deals with an interpretation of well log data (gamma ray (GR), resistivity, density, and neutron) from four wells, namely P-1, P-2, P-3 and P-4 in the study area of the Rio Del Rey basin. The well logs analysis indicates five potential sandstone reservoirs at the P-1, two at the P-2, four at the P-3 and six at the P-4. The neutron-density-GR logs highlight the sandstone gas reservoir characterized by high resistivity and crossover between neutron density. The neutron-density-GR cross-plot confirms the presence of sandstone containing hydrocarbons by a displacement of the cloud of points, from low to medium GR values, from the sandstone line to the left. Petrophysical parameters exhibit the value $12-41 \%$ for a volume of shale, $15-34 \%$ for effective porosity, $29-278 \mathrm{mD}$ for permeability and 3-63\% for water saturation. The three potential hydrocarbon reservoir saturation ranges from 22 to $45 \%$. The study will contribute to future offshore oil and gas exploration and development in the Rio Del Rey basin, based on the geological and geophysical characteristics of the reservoirs delineated.
\end{abstract}

Keywords Rio Del Rey $\cdot \log$ data $\cdot$ Sandstone reservoir $\cdot$ Petrophysical parameter

\section{Introduction}

Estimation of petrophysical properties such as porosity, permeability, the volume of shale, fluid saturation and thickness of reservoirs plays a vital role in the oil and gas industry (Kumar et al. 2016; Saadu and Nwankwo 2017). Well-logging data can accurately detect reservoir fluid volume and composition, if interpreted correctly and ideally calibrated to core data (Asquith et al. 2004; Darling 2005; Abudeif et al. 2016; Radwan 2018; Bai et al. 2019). Gas-bearing zones will show a greater separation in neutron-density crossover than oil zones, and oil can be inferred to be in places where low crossover magnitude is detected (Asquith

Janvier Domra Kana

janvierkana@yahoo.fr

1 Department of Mining, Petroleum, Gas and Water Resources Exploration, The Faculty of Mines and Petroleum Industries, University of Maroua, PO. Box: 08, Kaélé, Cameroon

2 Department of Physics, Teachers Training Higher School of N'Djamena, University of N'Djamena, Chad, P.O. Box 460, N'Djamena, Chad

3 Department of Earth Sciences, University of Yaoundé I, P.O. Box 812, Yaounde, Cameroon et al. 2004; Schechter 2010). In Cameroon, two types of basins define the general sedimentary context formation. The intracontinental type located mostly between Mamfe and Lake Chad, and the coastal basins type, which run along the Cameroonian Atlantic coast and are part of the large set of basins on the West African coast. The two main coastal sedimentary basins, namely: the RDR, representing the southeastern extension of the Niger Delta and the Douala/ Kribi-Campo Basin; a great epicontinental depression with a passive margin, resulting from the rifting of the South Atlantic. The volcanic line of Cameroon separates them (Societé National des Hydrocarbures 2005). The offshore part of the RDR basin represents one of Cameroon's main oil regions (Societé National des Hydrocarbures 2005). The RDR basin is therefore of major scientific and economic interest.

Numerous studies have been carried out by academic and legal entities (Oil Companies and others), in the RDR basin. These works have provided knowledge of this basin, both geologically and geodynamically. Coughlin et al. (1993) identified three structural provinces in the RDR and showed that the productive reservoirs are excellent and shallow, located within $2000 \mathrm{~m}$. They are identified by good-quality bedrock corresponding to Paleocene-Eocene marine clays. Mvondo (2010) has shown from an analysis of the seismic data and well, a clear succession

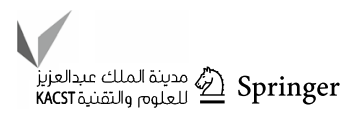


between two large sedimentary systems: the turbiditic channels of the Miocene and the delta of Miocene-real progression. Koum (2013) demonstrated the relative Plio-Pleistocene uplift of the southern coastal surface margin of the RDR thanks to the measurement of the river incision. This heightening is linked to the Pliocene activity of the Cameroon volcanic line and the numerous reactivations of post-Pan-African faults. Njoh and Agbor (2016) built environments in the basin by integrating paleontological, granulometric and petrographic data. Interpretation of these data involved major marine environments, medium neritic and then transitions between coastal and intertidal environments where there were deposits of Cretaceous sediments. Other works have been carried out in this basin but have remained unpublished, for example, that of, which concerned the production of a synthesis of old works carried over the basin. This unpublished internal report entitled "Kinematic, tectonic, sedimentary and petroleum synthesis of the RDR basin" presents ideas on the geology of the basin. In petrophysics, apart from the log studies carried out by oil companies, which are not very accessible, there are very few studies related to it. From this, it follows that the RDR basin is still less known from a petrophysical point of view. The best oil potential of the Rio Del Rey basin is found in its central part, unlike that of the Douala Basin. According to the National Hydrocarbon Company report, Cameroonian hydrocarbon production fell by $1.59 \%$ in April 2019 compared to 2018, during the same month. This drop-in production is mainly due to the depletion of fields. To remedy this deficit, the Cameroonian State has promoted several blocks in the Douala/Kribi-Campo basin and that of Rio Del Rey. Prospecting for these blocks begins with a better understanding of geological and petrophysical knowledge of neighboring or operating fields in the basin. A major query then arises concerning the quality of the source formations, reservoirs and covers of the Rio Del Rey basin. In this context, a study on the characterization of reservoirs in the Rio Del Rey basin is therefore beneficial.

The Rio Del Rey (RDR) basin is located at the edge of the Gulf of Guinea and belongs to the large group of basins of the West African Margin. According to Societé National des Hydrocarbures (2015), the offshore part of the RDR basin represents one of Cameroon's oil regions. This study proposes to analyze $\log$ data from four oil wells $P 1, P 2, P 3$ and $P 4$ offshore of the southwest zone of the Rio Del Rey basin in order to highlight the characteristics of the reservoirs of the basin and consequently to evaluate the quality of the latter, through their petrophysical properties.

\section{The Rio Del Rey basin setting}

The study area located between latitude $4^{\circ}$ and $5^{\circ}$ North and longitude $8^{\circ} 20^{\prime}$ and $9^{\circ} 10^{\prime}$ East, the RDR basin (Fig. 1), is one of the coastal basins of the southwest region of Cameroon and represents the southeastern extension of the Niger Delta into the Gulf of Guinea (Coughlin et al. 1993). The RDR basin is bordered by Nigeria's Niger Delta Basin to the west and northwest, by the Rio Muni basin in Equatorial Guinea to the south, to the north by the Rumpi hills and to the east by the Cameroon Volcanic Line which separates the RDR basin from the Douala/Kribi-Campo basin (Coughlin et al. 1993). It covers an area of approximately $7000 \mathrm{~km}^{2}$ offshore, and at its central part, the sediments are estimated to be less than $12 \mathrm{~km}$ thick, but generally, this thickness is estimated at around $6 \mathrm{~km}$ (Doust 1990). The formation and tectonic evolution of this basin like all the other basins bordering the West African coast are closely linked to the rifting process which permitted the opening of the South Atlantic and the formation of the Gulf of Guinea, by the separation of African and South American continents during the Albo-Aptian (Rabinovich 1979). Sedimentation in the basin began during the Cretaceous, and the sequences are linked to sedimentation in the Benue trench, the Douala basin and other basins in southeast Nigeria (Nair 1981; Nguene 1992; Petters 1995; Njoh 2008, 2010). Three main diachronic formations, each corresponding to very specific environments, are encountered in this basin (Njoh and Agbor Taku 2016): (1) The Akata Formation of the Late Paleocene, formed of prodeltaic marine clay covering the sediments from the Cretaceous; (2) the recent Agbada Formation of the Oligocene-Miocene covering the Akata Formation and composed of a delta front with alternating sand and clay; (3) the Recent Pliocene superficial formation of Benin, made up of fluvial sands and sandstones from the coastal plains, clays of the Agbada, the Akata and those of the Cretaceous (Kita clay).

The RDR stratigraphy can be divided into two units: a Pre-Deltaic unit from the Paleocene to Miocene and a deltaic unit.

The Upper Paleocene was encountered in a well in the locality of Yaounde and has been clay identified. The Eocene series generally consist of clays deposited in a marine environment. A small amount of volcanic material may also be present in these series. An interesting turbiditic system has been discovered in deep water environments: the Ongue and Debunsha sands. A similar repository system continued to be developed during the Lower Miocene.

The deltaic sediments belong to the eastern extension of the Niger Delta. Overall, they form a sequence of prograding deposits deposited mainly during the late Miocene and early Pliocene. This sedimentation was made of alternating sand and clay forming the Agbada Formation. Beyond the delta front, unconsolidated, water-saturated clays are deposited and form the Akata Formations (Fig. 2). 
(a)

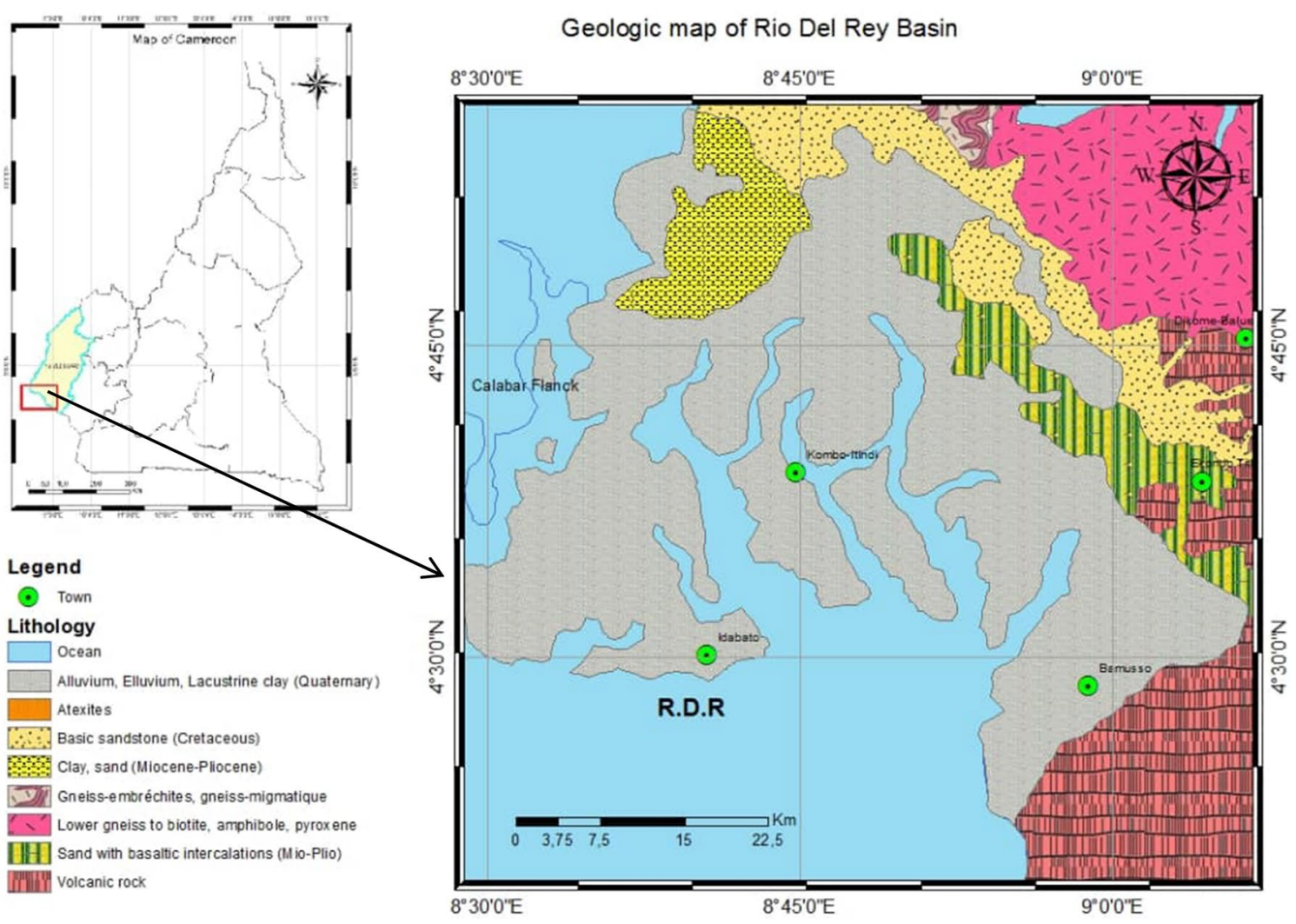

(b)

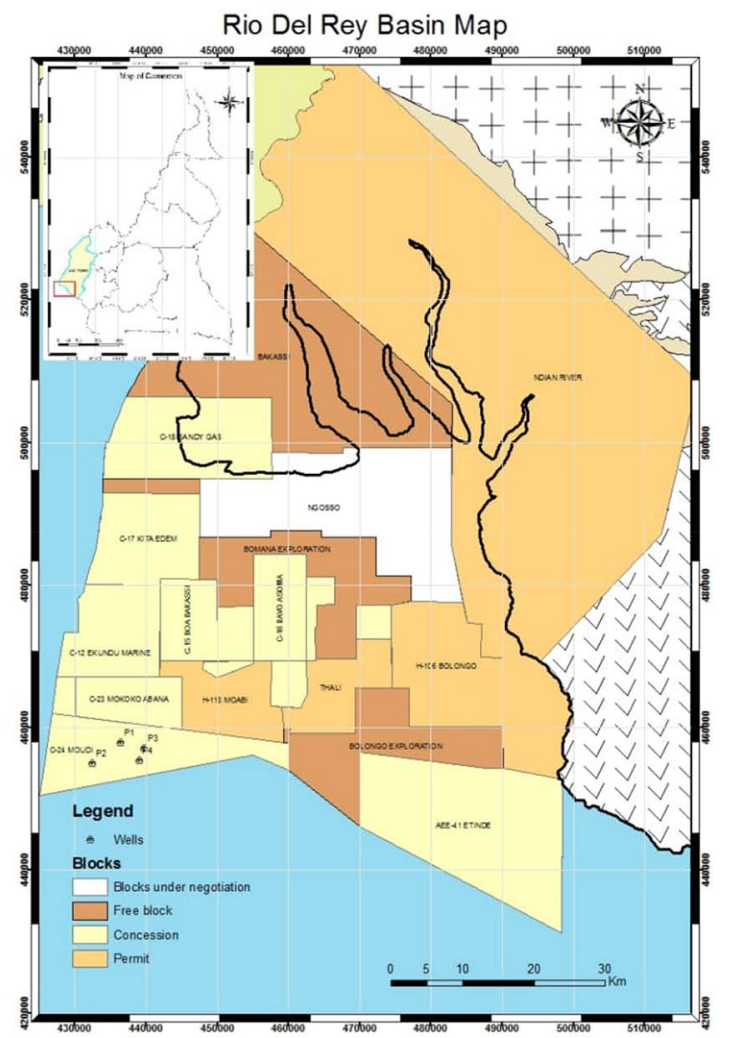

Fig.1 Geological map and location of the RDR basin (modified after Dumort 1968) (a), different bloc of RDR basin showing the well position $P 1, P 2, P 3$ and $P 4$ 


\section{Methodology}

A multi-method approach was used for the analysis of logs in the work environment. The qualitative interpretation is based mainly on the observation and analysis of log responses. The "Quick look" method, which is a rapid interpretation of log developed by Serra (1979), is therefore used for this purpose to identify the lithology, the potential reservoirs, the producing levels and the fluids they contain. The quantitative characterization of the reservoirs is done using methods based on empirical relations integrated into the Techlog software.
The volume of shale is determined quantitatively by applying different methods. If the reservoir contains some minerals like feldspars, uranium and potassium, the GR value can be influenced and the neutron-density method is necessary (Attia 2015). Else, the analysis of the natural gamma-ray log response can be used.

These minerals are not present in our reservoir, and radioactive clay can be identified. Clays, areas with GR values $\geq 90$ API; sand (clean), areas with GR values $\leq 50 \mathrm{API}$, and values between 50 and 90 API $(50<$ GR $<90$ API $)$, correspond to sandy-clay areas (Meunier 2011; Delalex 2014).

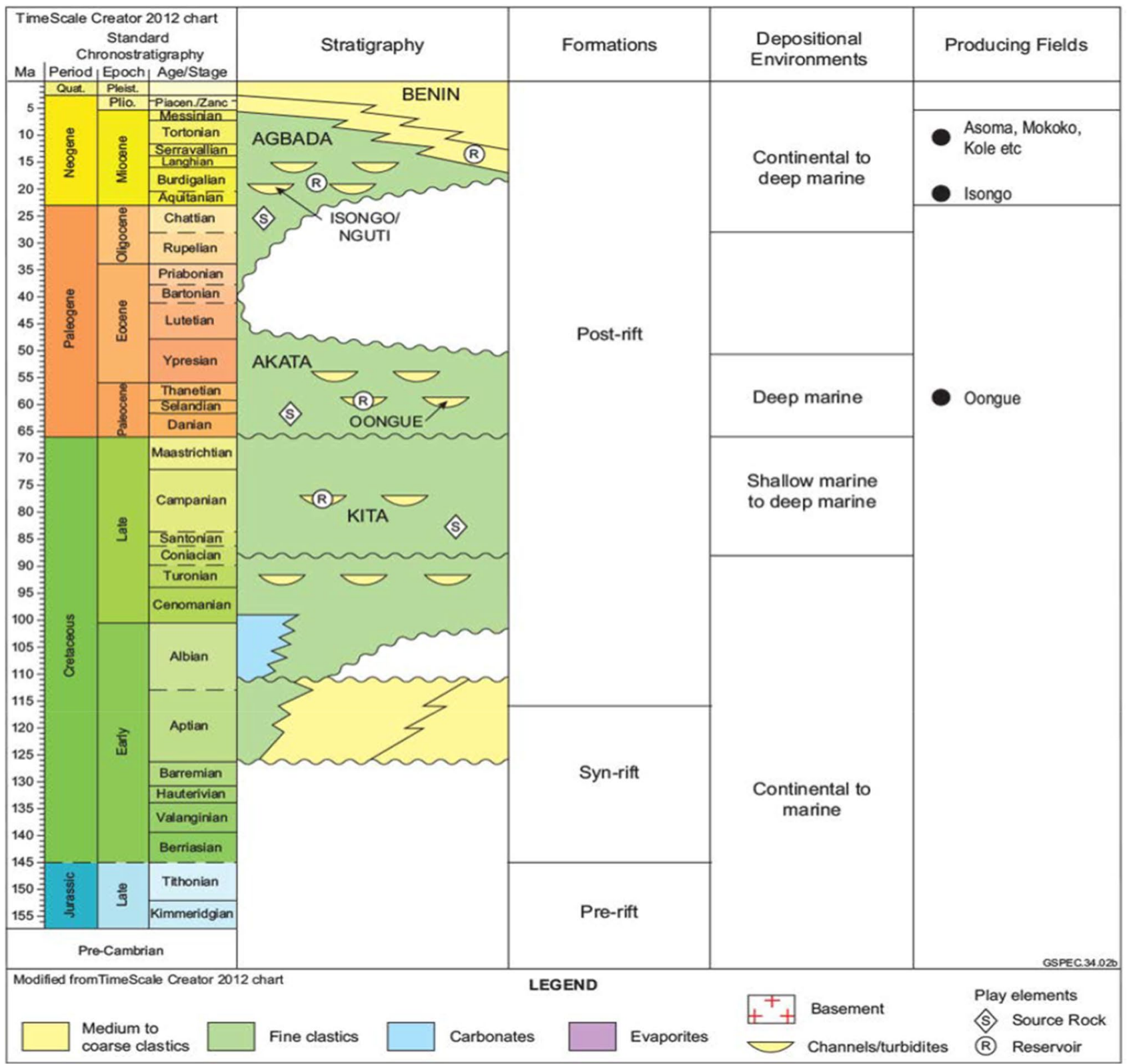

Fig. 2 Rio Del Rey basin chronostratigraphic chart (Societé National des Hydrocarbures 2015) 
The clay volume $V_{\mathrm{sh}}$ is estimated from the linear relation applied to natural gamma-ray $\operatorname{logs}$ (Asquith 1982).

$V_{\mathrm{sh}}=I_{\mathrm{GR}}=\frac{\mathrm{GR}_{\mathrm{read}}-\mathrm{GR}_{\text {min }}}{\mathrm{GR}_{\max }-\mathrm{GR}_{\min }}$

where:

$\mathrm{GR}_{\text {read }}:$ GR value of the bank read directly from the log (API) ;

$\mathrm{GR}_{\min }$ : Minimum GR value of the same bank (API);

$\mathrm{GR}_{\max }$ : Maximum GR value of the same bank (API);

$I_{\mathrm{GR}}:$ Gamma ray radiation index ;

$V$ sh : Volume of clay.

In terms of the clay content of these intervals, the quality of potential reservoirs identified shall be specified: the interval identified is considered sandy (sandstone) for clay content values between 10 and 25\%; sandy-clay (sandstoneclay) for those ranging from 25 to $35 \%$ : and very clayey sand (strongly clayey sandstone) for clay content values ranging from 35 to 50\% (Serra 1979).

A reference line defined on the gamma-ray curve makes it possible to separate the reservoir formations from the clay formations. This line is established as a function of a limit value of gamma ray, $\mathrm{GR}_{\text {cutoff }}$, which is calculated in turn from a limit clay volume $\left(V_{\text {shCutoff }}\right)$, which is approximately $45 \%$ (Staffan 2010). Beyond the value of the reference line $\left(\mathrm{GR}_{\text {cutoff }}\right)$, the formation is no longer considered a reservoir.

$\mathrm{GR}_{\text {Cutoff }}=V_{\text {Sh cutoff }} *\left(\mathrm{GR}_{\max }-\mathrm{GR}_{\min }\right)+\mathrm{GR}_{\text {min }}$

where:

$$
\begin{gathered}
\mathrm{GR}_{\min } \text { : the gamma ray value read directly } \\
\text { in front of a clean sandstone bed ; } \\
\mathrm{GR}_{\max } \text { : the gamma ray value read directly } \\
\text { in front of a clay bed ; }
\end{gathered}
$$

The potential reservoirs correspond to sand/sandstone intervals, with an amplitude greater than or equal to $10 \mathrm{~m}$ (Kiki 2018). The resistivity log (ILD) makes it possible to determine the presence of hydrocarbons. The low resistivity attests to the presence of water in the formations, while the medium ( $20 \mathrm{Ohm} . \mathrm{m})$ and very high resistivity indicate the presence of hydrocarbons (oils and gases) (Meunier 2011).

The combination of the neutron and density log curves makes it possible to deduce the probable nature of the fluids that could be contained in the formations. In a reservoir potentially containing hydrocarbons, the density curve evolves to the left of the neutron curve: the inversion effect between the density and neutron curves. The assessment of the inversion effect or of the difference between the curves of the neutron and density log responses makes it possible to decide on the probable nature of the fluid. This difference between the density curve and the neutron curve is generally less than two (2) or three (3) divisions in the oil zone and greater than three (3) divisions in the gas zone (Meunier 2011; Varhaug 2016). The porosity density is obtained from Wyllie's formula.

$\emptyset_{D}=\frac{\rho_{b}-\rho_{\mathrm{ma}}}{\rho_{f}-\rho_{\mathrm{ma}}}$

$\emptyset_{D}$ : Overall density read opposite the given study level in $(\mathrm{g} / \mathrm{cm} 3))$;

$\rho_{\text {ma }}:$ Density of the matrix ;

$\rho_{f}$ : Fluid density;

$\rho_{b}$ : Porosity given by density tools.

Alongside this density porosity, the porosity is determined by the "Quick look" method, which combines neutron and density logs porosity $\left(\emptyset_{N}, \emptyset_{D}\right)$. The total $\emptyset_{T}$ and effective porosity $\emptyset_{e}$ are plotted by the following equations.

$\emptyset_{T}=\frac{\emptyset_{N}+\emptyset_{D}}{2}$

$\emptyset_{e}=\emptyset_{T} \times\left(1-V_{\mathrm{sh}}\right)$

In the case of this study, we will use the relation of Coates and Dumanoir that permits us to obtain the permeability in the clean sands as in the sand-clay formations.

$K=\frac{C . \emptyset^{2 j}}{j^{4}\left(R_{w} / R_{\mathrm{tirr}}\right)}$

where:

$K$ : Permeability $(\mathrm{mD})$;

$R_{w}$ : Resistivity of formation water at formation temperature ;

$R_{t . i r r}$ : Real resistivity of the formation. at irreducible water saturation;

$\emptyset$ : Porosity ;

Cet $j$ : Coates and Dumanoir constants.

In the case of non-proper formations, several relations have been established depending on the nature of the clays, namely: Simondoux, Modified Simondoux, Indonesian. In the case of this study, the water saturation is estimated by the method of Juharz.

$\frac{1}{R_{t}}=\frac{\emptyset_{T}^{m} \cdot S_{w T}^{n}}{a \cdot R_{w}}\left(1+\frac{B \cdot Q_{\mathrm{Vn}}}{S_{w T}}\right) \quad$ where $\quad Q_{\mathrm{Vn}}=\frac{V_{\mathrm{sh}} \cdot \emptyset_{s h}}{\emptyset_{T}}$ 
where:

$S_{w T}:$ Total water saturation;

$V_{\mathrm{sh}}:$ Volume of clay

$\phi_{T}:$ Total Porosity ;

$\phi_{s h}:$ Clay Porosity ;

$a$ : Formation factor ;

$n$ : saturation exponent, which

can vary between 1.2 and 2.2 ;

$m$ : Cementation factor.

Due to the water saturation, $S_{\omega}$, it will be possible to determine the hydrocarbon saturation in the virgin zone $S_{\mathrm{hc}}$ with the following formula:

$S_{\mathrm{hc}}=1-S_{\omega}$

\section{Results and discussion}

\section{Lithological characteristics}

Identification of lithofacies is very crucial because petrophysical parameters such as porosity, permeability and saturation depend on the type of facies. The analysis of the gamma-ray log and the superposition of the neutron-density log made it possible to determine the lithological nature of the layers crossed (Fig. 3), from the predefined electrofacies.

The cross-plots of neutron-density-gamma ray (Fig. 4) of the studied wells, allow verifying the lithology obtained from the interpretation of the gamma rays and the superposition of the neutron-density logs.

The four cross-plots show a configuration of a clayey sandstone environment. The points of lower to higher values GR around the sandstone line reflect the presence of sandstones, and the displacement of the cloud points of lower to higher GR values reflects the presence of clayey sandstones (Fig. 4). The presence of clays is materialized by the displacement of the cloud from the average points to the high GR values of the dolomite line to the right.

The cross-plot of well P1 (Fig. 4) shows a variation in porosity between approximately 35 and $45 \%$. Some points of low value gamma ray are observed around the line of sandstones: this proves a very weak presence of very porous sandstones. There are also low to medium gamma-ray values around the limestone and dolomite lines, characterizing the presence of porous carbonate formations. In addition, well P3 shows a high occurrence of clays, indicated on the crossplot by an abundance of medium to high gamma-ray value points beyond (right) the dolomite line.
The cross-plot of the well P2 (Fig. 4) shows a variation in porosity between 40 and $45 \%$. A few points of low gamma-ray values are observed around the sandstone line: this proves a very low presence of very porous sandstones. There are also low to medium gamma-ray values around the limestone and dolomite lines, thus characterizing the presence of porous carbonate formations.

In addition, well P3 shows a high occurrence of clays, indicated on the cross-plot by an abundance of medium to high gamma-ray value points beyond (right) the dolomite line. The cross-plot of well P3 (Fig. 4) shows a porosity of approximately $46 \%$. Low gamma-ray values are observed around the sandstone line; this proves the presence of very porous sandstones. There are also low to medium gammaray values around the limestone and dolomite lines, characterizing the presence of porous carbonate formations. In addition, well P3 shows a high occurrence of clays, indicated on the cross-plot by an abundance of medium to high gamma-ray value points beyond (right) the dolomite line.

The cross-plot of well P4 (Fig. 4) shows a variation in neutron porosity between approximately 32 and $40 \%$. Low gamma-ray values are observed around the sandstone line; this proves the presence of very porous sandstones/sand. There are also low to medium gamma-ray values around the limestone and dolomite lines, thus characterizing the presence of porous carbonate formations. In addition, the well $\mathrm{P} 4$ shows a high occurrence of clays, indicated on the cross-plot by an abundance of medium to high gamma-ray value points beyond (right) the dolomite line.

\section{Delimitation of reservoir bearing and shale volume}

The analysis of the gamma-ray log allows calculating of the volume of shale $\left(V_{\mathrm{sh}}\right)$ and potential reservoir stage. The log of clay content according to the volume has been plotted (Fig. 5). The potential reservoirs which correspond to intervals of low gamma-ray values (less than the $G_{\text {Rcutoff }}$ ), and whose amplitude is greater or equal to $10 \mathrm{~m}$ have been identified (Fig. 5).

In well P1, five (05) potential reservoirs (R1, R2, R3, R4, R5) were detected, with varying thicknesses between $11.7 \mathrm{~m}$ (R4) and $75.6 \mathrm{~m}$ (R1). In well P2, two (02) potential reservoir levels have been identified, with thicknesses of approximately $11 \mathrm{~m}$. In well P3, four (04) potential reservoirs were detected, with varying thicknesses between $12.7 \mathrm{~m} \mathrm{(R1)} \mathrm{and}$ $37.19 \mathrm{~m}$ (R3). In well P4, six (06) potential reservoirs were identified, with varying thicknesses between $15.12 \mathrm{~m}$ (R2) and $38.17 \mathrm{~m}$ (R4).

The average values of the clay content show that the potential reservoirs are sandy with clay volumes 


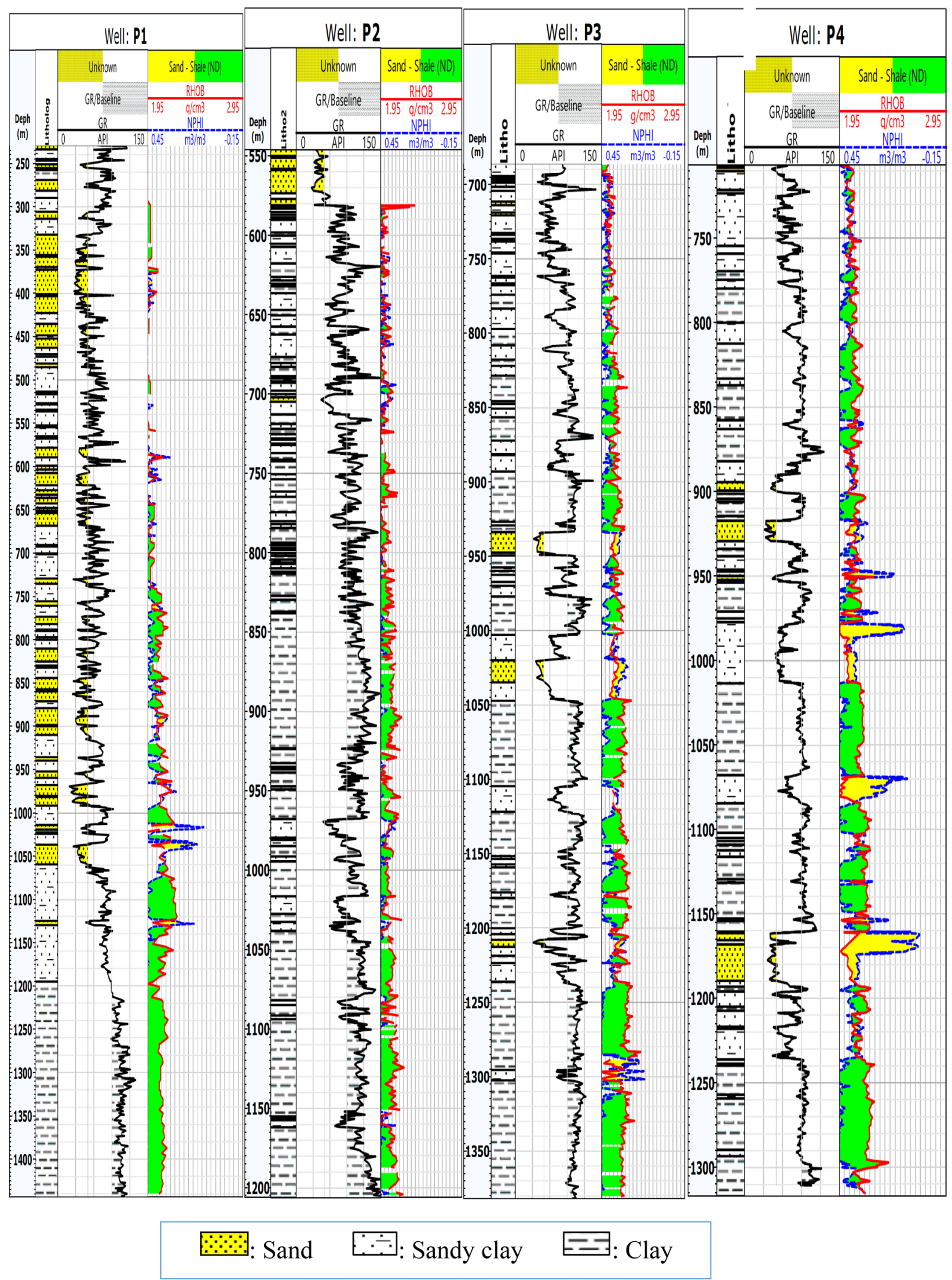

Fig. 3 Result of lithological nature of the layers crossed by wells 

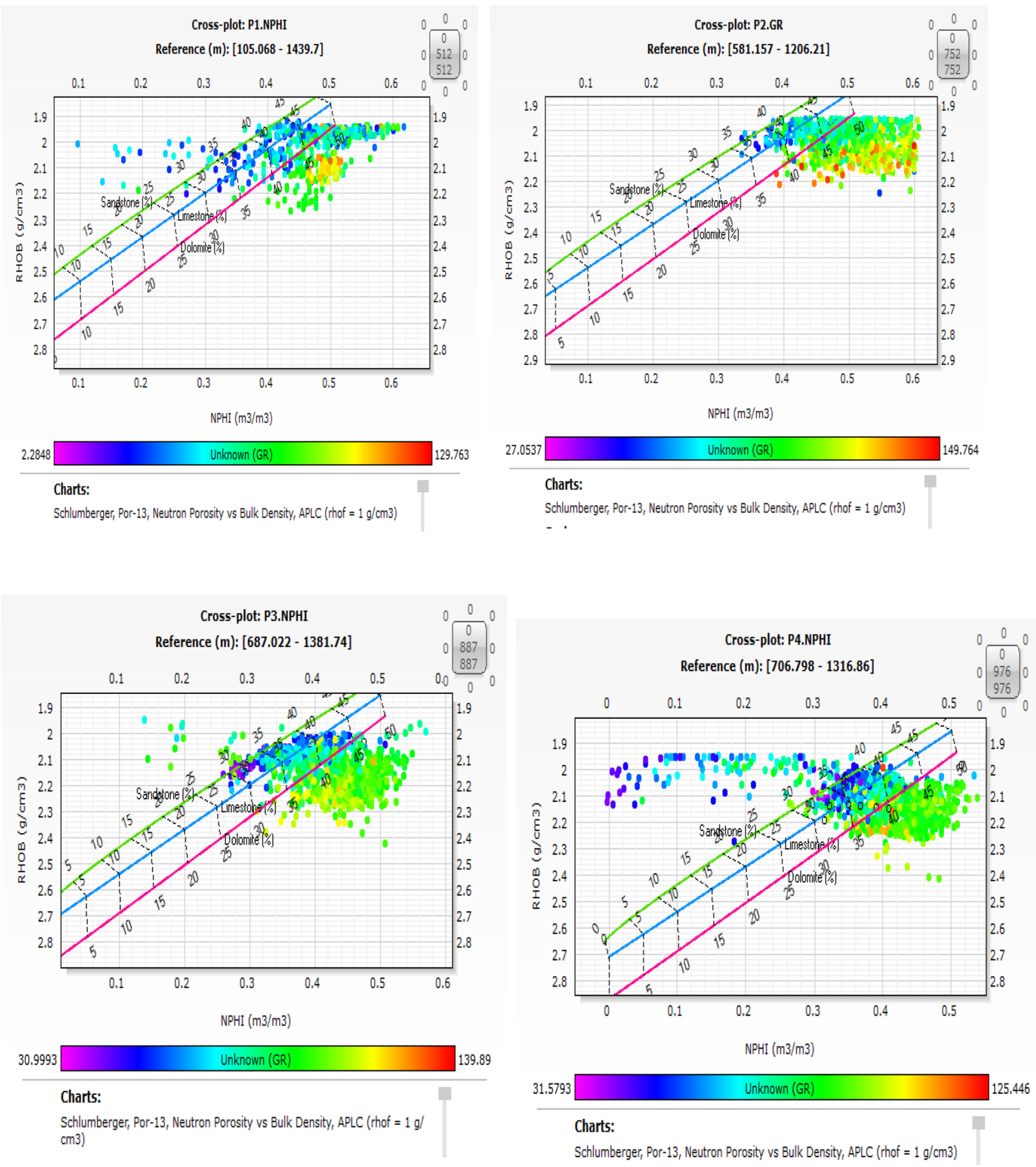

Fig. 4 Cross-plots of neutron-density porosity of well $P 1, P 2, P 3$ and $P 4$

varying between 12.7 and $24.23 \%$ (R2, R3 and R5 of the well P1; R1 of the well P2; R1 and R3 from well $\mathrm{P} 3$ and R1, R2 and R5 from well P4) and sandy clay with clay volumes between 27.58 and $32.63 \%$. We note a strong occurrence of sandy reservoirs and the presence of some very clayey sandy reservoirs. The potential reservoir level with clayey content and thickness is given in Table 1. 


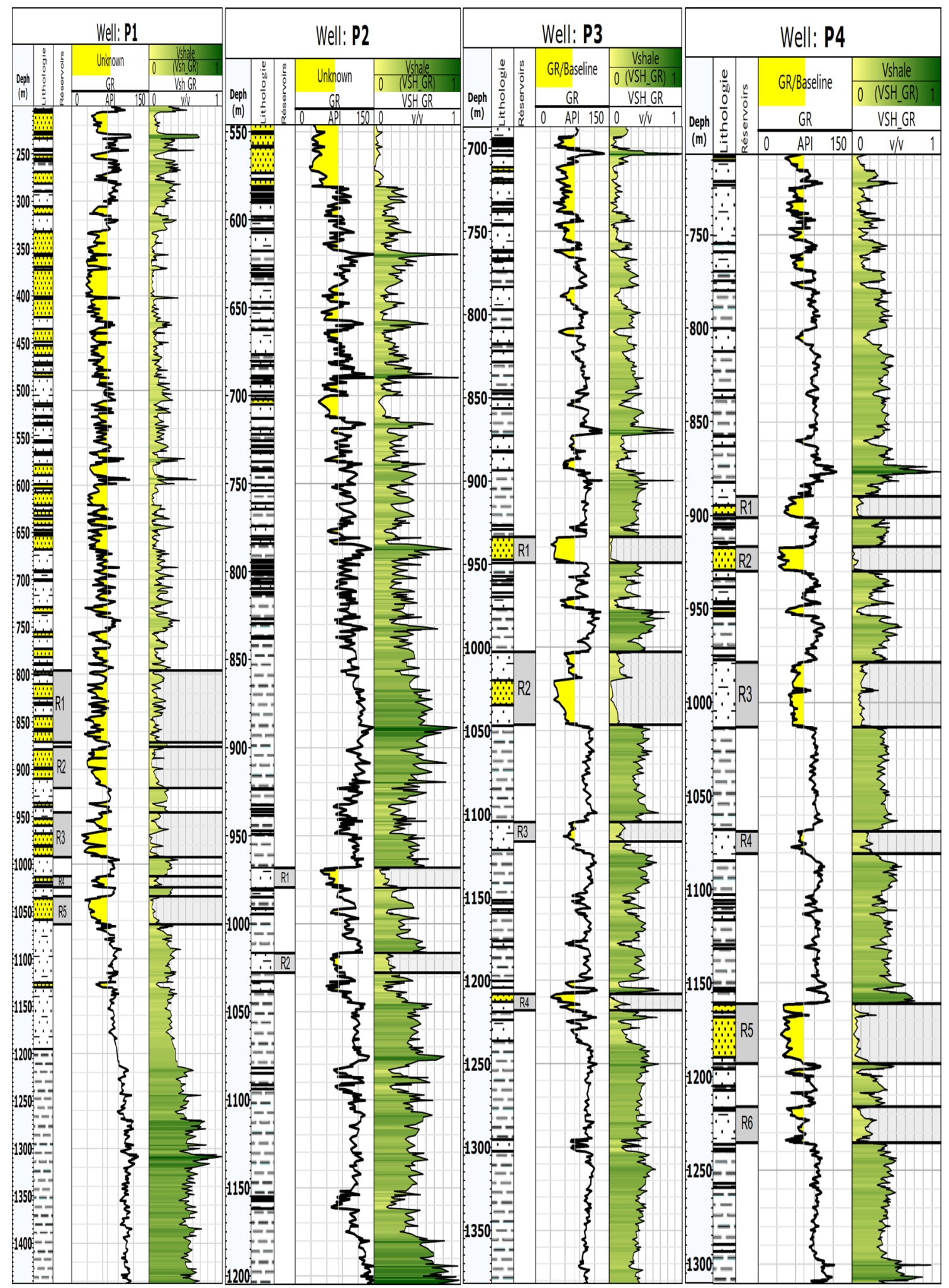

$\because$ : Sand $\quad \because \div$ : Sandy clay $\quad \Xi$ : Clay $\quad \square$ : Reservoir

Fig. 5 Result of clay content $(V s c)$ and reservoir level 
Table 1 Clay content and nature of potential reservoirs at the level of the different wells

\begin{tabular}{|c|c|c|c|c|}
\hline $\begin{array}{l}\text { Potential } \\
\text { reservoirs }\end{array}$ & Extent (m) & Thickness (m) & $V_{\mathrm{Sh}}(\%)$ & Nature \\
\hline \multicolumn{5}{|l|}{ Well P1 } \\
\hline$R 1$ & 796-871.6 & 75.6 & 27.58 & Sandy clay \\
\hline$R 2$ & 876.2-919.7 & 43.5 & 23.43 & Sandy \\
\hline$R 3$ & 945.4-992.7 & 47.3 & 24.23 & Sandy \\
\hline$R 4$ & $1012.7-1024.4$ & 11.7 & 28.7 & Sandy clay \\
\hline$R 5$ & $1034.4-1063.8$ & 29.4 & 20.68 & Sandy \\
\hline \multicolumn{5}{|l|}{ Well P2 } \\
\hline$R 1$ & 968.3-979.5 & 11.2 & 32.89 & Sandy clay \\
\hline$R 2$ & $1016.6-1027.6$ & 11 & 41.15 & $\begin{array}{l}\text { Very clayey } \\
\text { sand }\end{array}$ \\
\hline \multicolumn{5}{|l|}{ Well P3 } \\
\hline$R 1$ & 933.9-949.5 & 15.6 & 12.7 & Sandy \\
\hline$R 2$ & 1002.9-1046.7 & 43.8 & 28.73 & Sandy clay \\
\hline$R 3$ & $1104.8-1116.5$ & 11.7 & 37.19 & $\begin{array}{l}\text { Very clayey } \\
\text { sand }\end{array}$ \\
\hline$R 4$ & $1208.1-1218$ & 9.9 & 22.22 & Sandy \\
\hline \multicolumn{5}{|l|}{ Well P4 } \\
\hline$R 1$ & 889.6-901 & 11.4 & 23.55 & Sandy \\
\hline$R 2$ & 916.7-929.9 & 13.2 & 15.12 & Sandy \\
\hline$R 3$ & 978.4-1012.9 & 34.5 & 29.21 & Sandy clay \\
\hline$R 4$ & $1068.5-1080.4$ & 11.9 & 38.17 & $\begin{array}{l}\text { Very clayey } \\
\text { sand }\end{array}$ \\
\hline$R 5$ & 1161.16-1193.1 & 31.94 & 20.12 & Sandy \\
\hline$R 6$ & $1216-1235.3$ & 19.3 & 32.63 & Sandy clay \\
\hline
\end{tabular}

\section{Petrophysical parameter}

In well $P_{1}$, the analysis and interpretation of the result of $\log$ (Fig. 6) exhibit five potential sandy to sandy-clay reservoir levels, with varying thicknesses between 11.7 and $75.6 \mathrm{~m}$. The porosity of these reservoir levels ranges from good to excellent with values between 0.26 and 0.4 . A decrease of these values is noted as a function of depth, and this is explained by the compaction caused by the overload sediments. The permeability of these five reservoir zones varies between 81.29 and $204.06 \mathrm{mD}$, characterizing average to good permeability. They equally decrease with depth, so they evolve synchronously with the porosity. The water saturation of these reservoirs $\left(R_{1}, R_{2}, R_{3}, R_{4}\right.$ and $\left.R_{5}\right)$ is $24.75 \% ; 23.48 \% ; 22.59 \% ; 33.67 \%$ and $22.55 \%$, respectively.

Two potential reservoir levels were identified in well $P_{2}$ (Fig. 6). They are sandy clay $\left(R_{1}\right)$ and very clayey sand $\left(R_{2}\right)$, with thicknesses of approximately $11 \mathrm{~m}$. The porosities of these reservoirs are 0.38 and 0.43 , respectively. The high porosity of reservoir $R_{2}$ at a depth of approximately $1020 \mathrm{~m}$ is induced by the micropores of the clays, which are very present in this reservoir. The permeabilities of the two reservoirs increase with depth and are estimated at $153.6 \mathrm{mD}$ and
$278.5 \mathrm{mD}$, respectively. The high permeability of $R_{2}$ could be due to natural microfissures or fractures.

In well, $P_{3}$ (Fig. 6), four potential reservoir levels with heights varying between $10 \mathrm{~m}$ and $43.8 \mathrm{~m}$ were identified. Reservoirs $R_{1}$ and $R_{4}$ are sand; however, reservoirs $R_{2}$ and $R_{3}$ are sandy clay and very clayey sand, respectively. These reservoir levels have excellent porosities: $R_{1}, R_{2}$ and $R_{3}$ have an identical porosity estimated at approximately 0.34 , while that of $R_{4}$ is evaluated at 0.32 . The permeability decreases with respect to the depth, between $R_{1}$ and $R_{3}$ (106.6-30.34 mD), and then increases at the level of $R_{4}$ with a value of $44.35 \mathrm{mD}$. These permeabilities range from poor to moderate. The high permeability of $R_{4}$ is thought to be due to natural fractures connecting the isolated pores. Well $P 3$ does not show any evidence which could indicate the presence of hydrocarbons. The water saturation of these reservoir levels varies between 3.37 and $43.86 \%$.

Six potential reservoir levels, with thicknesses ranging between 11.4 and $34.5 \mathrm{~m}$, were identified in well P4 (Fig. 6). These reservoir levels are generally sandy $(R 1$, $R 2$ and $R 5$ ) to sandy clay ( $R 3$ and $R 6$ ), with the $\mathrm{R} 4$ reservoir very clayey sand. Their porosities range from average to excellent and vary between 0.18 and 0.36 . The porosity decreases up to $R 5$ and then increases at the level of reservoir $R 6$ with a porosity of 0.34 . The permeabilities are poor $(29.81 \mathrm{mD})$ to medium $(70.09 \mathrm{mD})$. We note at the level of $R 6$, an increase in porosity and permeability compared to $R 5$, which would be due to the micropores present in the clays and the natural microfractures, respectively. The water saturations vary between $37.48 \%$ and $73.27 \%$. The reservoir $R 5$, likely to contain hydrocarbons (gas at a height of about $12 \mathrm{~m}$ and oil at a height of about $5.8 \mathrm{~m}$, in this case), has a water saturation of $54.27 \%$, that to say $45.73 \%$ of hydrocarbon saturation. The results are summarized in Table 2.

Analysis of the resistivity $\log$ shows that the zones whose resistivities vary between 20 and 2000 Ohm.m are therefore colored in yellow (Fig. 6). A strong gas effect is evidenced from the cloud point distribution in the neutron-density cross-plot of well $P 1$ and well $P 4$ (Fig. 4). The sandstone reservoirs corresponding to these zones are considered as potentially containing the hydrocarbons. In this context, two reservoirs ( $R 4$ and $R 5)$ in well $P 1$ and reservoir $R 5$ in well $P 4$ can potentially contain hydrocarbons. The results of cloud point cross-plotting are similar to those obtained by Upal (2020) in the Sangu gas field, offshore, Bangladesh. So, gas is observed in $R 4$ with a slope of about $2.5 \mathrm{~m}$ (between 1015.3 and $1017.8 \mathrm{~m}$ ) and in the $R 5$ over a height of about 1.6 (between 1039.1 and $1040.7 \mathrm{~m}$ ), well $P 1$. In well $P 4$, the reservoir that may potentially contain hydrocarbons, i.e., reservoir $R 5$, shows the presence of gas over approximately $12 \mathrm{~m}$ of coastline (between 1161.9 and $1173.9 \mathrm{~m}$ ) and oil on a height of about $5.8 \mathrm{~m}$ (between 1173.9 and $1179.7 \mathrm{~m}$ ). 

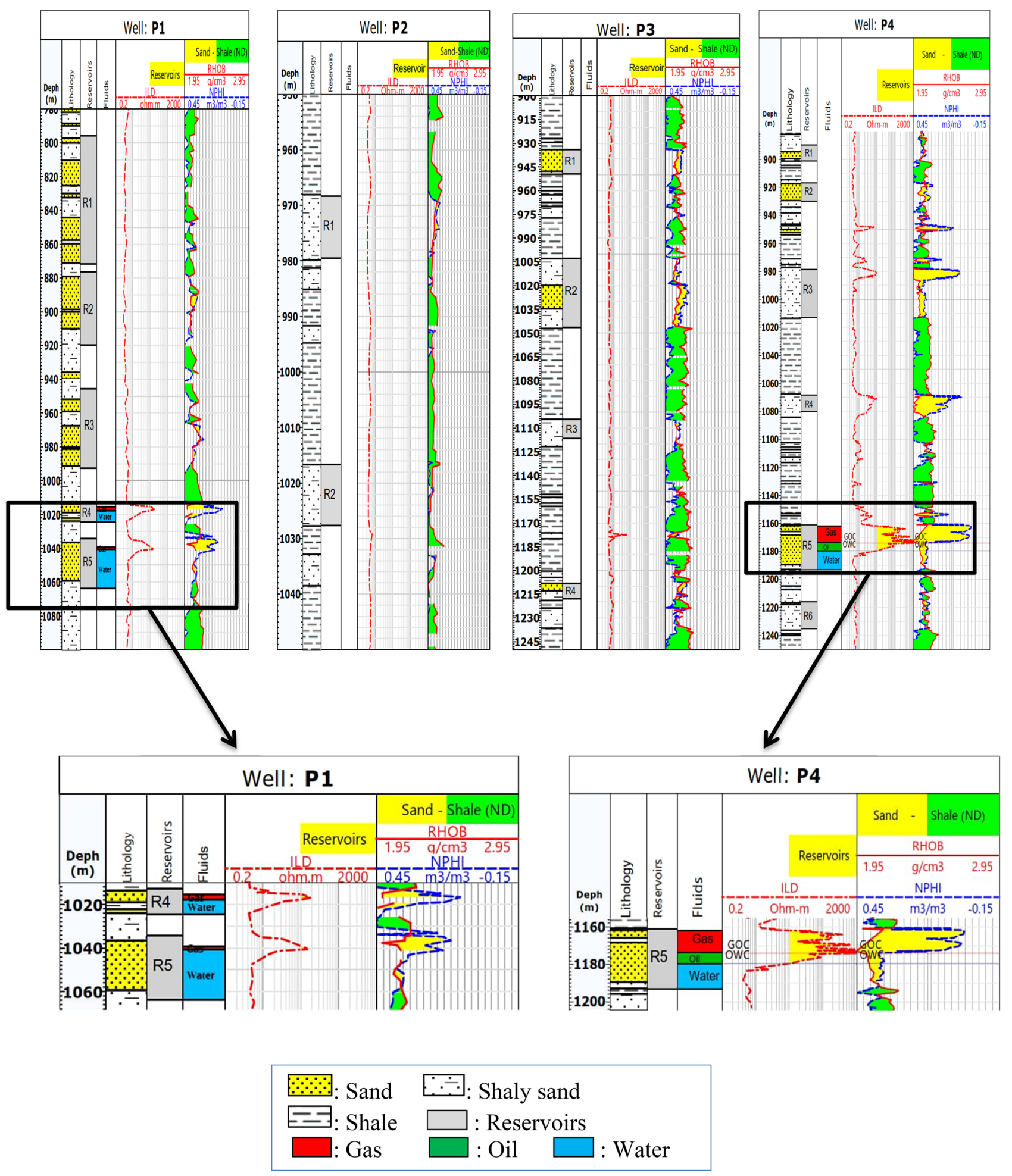

Fig. 6 Result of lithology, reservoirs and fluids of well $P 1, P 2, P 3, P 4$

In view of these characteristics, we can affirm that the potential Miocene reservoir levels identified in the four wells studied in the southwestern portion of the RDR basin have good reservoir rock qualities. Our findings will serve as useful data for future exploration campaigns and enhance the petrophysical parameters of the reservoirs of the RDR basin. The prospecting of blocks promoted by the state of Cameroon begins with a better understanding of geological and 
Table 2 The petrophysical parameters (porosity, permeability and saturations) of potential reservoirs at the level of the different wells

\begin{tabular}{|c|c|c|c|c|c|c|c|}
\hline \multirow[t]{2}{*}{ Well } & \multirow{2}{*}{$\begin{array}{l}\text { Potential } \\
\text { reservoirs }\end{array}$} & \multirow[t]{2}{*}{ Nature } & \multicolumn{2}{|c|}{ Porosity $(V / V)$} & \multirow[t]{2}{*}{$K(\mathrm{mD})$} & \multirow[t]{2}{*}{$\mathrm{Sw}(\%)$} & \multirow[t]{2}{*}{ Shc } \\
\hline & & & $\Phi_{D}$ & $\Phi_{\mathrm{QL}}$ & & & \\
\hline \multirow[t]{5}{*}{$P 1$} & $R 1$ & Sandy clay & 0.35 & 0.4 & 204.06 & 24.75 & \\
\hline & $R 2$ & Sandy & 0.35 & 0.38 & 158.43 & 23.48 & \\
\hline & $R 3$ & Sandy & 0.32 & 0.35 & 122.76 & 22.59 & \\
\hline & $R 4$ & Sandy clay & 0.36 & 0.26 & 91.07 & 33.67 & 66.33 \\
\hline & $R 5$ & Sandy & 0.34 & 0.27 & 81.29 & 22.55 & 77.45 \\
\hline \multirow[t]{2}{*}{$P 2$} & $R 1$ & Sandy clay & 0.36 & 0.38 & 153.6 & 34.42 & \\
\hline & $R 2$ & Very clayey sand & 0.38 & 0.43 & 278.5 & 35.9 & \\
\hline \multirow[t]{4}{*}{$P 3$} & $R 1$ & Sandy & 0.33 & 0.34 & 106.6 & 14.56 & \\
\hline & $R 2$ & Sandy clay & 0.33 & 0.34 & 56.23 & 30.83 & \\
\hline & $R 3$ & Very clayey sand & 0.32 & 0.34 & 30.34 & 43.86 & \\
\hline & $R 4$ & Sandy & 0.32 & 0.32 & 44.35 & 3.374 & \\
\hline \multirow[t]{6}{*}{$P 4$} & $R 1$ & Sandy & 0.36 & 0.36 & 70.09 & 47.65 & \\
\hline & $R 2$ & Sandy & 0.35 & 0.36 & 55.64 & 37.48 & \\
\hline & $R 3$ & Sandy clay & 0.38 & 0.29 & 89.5 & 55.41 & \\
\hline & $R 4$ & Very clayey sand & 0.4 & 0.22 & 39.73 & 73.27 & \\
\hline & $R 5$ & Sandy & 0.36 & 0.18 & 29.81 & 54.27 & 45.73 \\
\hline & $R 6$ & Sandy clay & 0.33 & 0.34 & 52.75 & 64.24 & \\
\hline
\end{tabular}

petrophysical knowledge of neighboring or operating fields in the basin. In this context, a study on the characterization of reservoirs in the Rio Del Rey basin is therefore beneficial.

\section{Conclusion}

The well-logging analysis showed that two to six potential reservoirs were identified on an ad hoc basis in the different wells studied. These reservoir levels are generally sand to clayey sand, with percentages of clay from 12.7 to $32.89 \%$; however, there are some very clayey sand levels with clay volumes ranging between 37.19 and $41.15 \%$. They, therefore, have significant lithological qualities. The porosities of the different potential reservoirs, obtained by the "Quick look" method $\left(\Phi_{\mathrm{QL}}\right)$, vary between 0.18 and 0.43 with a majority of these values greater than $30 \%$, characterizing the excellent porosities of these reservoir formations. The majority of the potential reservoirs identified in the different wells have average permeability values varying between 52.75 and $278.5 \mathrm{mD}$, with the exception of reservoirs $R 3$, $R 4$ of well $P 3$ and reservoirs $R 4, R 5$ of well $P 4$ showing values less than $50 \mathrm{mD}$ and characterizing poor permeability. The permeabilities of the reservoirs of well $P 1$ show relatively higher permeability values than those of the reservoirs of the $P 2, P 3$ and, $P 4$ wells.

Acknowledgements The authors declare that they have no known competing financial interests or personal relationships that could have appeared to influence the work reported in this paper. The authors also thank the associate editor and three anonymous reviewers for their constructive feedback and suggestions on the manuscript, which improve its quality.

Funding No funds, grants, or other support was received.

Open Access This article is licensed under a Creative Commons Attribution 4.0 International License, which permits use, sharing, adaptation, distribution and reproduction in any medium or format, as long as you give appropriate credit to the original author(s) and the source, provide a link to the Creative Commons licence, and indicate if changes were made. The images or other third party material in this article are included in the article's Creative Commons licence, unless indicated otherwise in a credit line to the material. If material is not included in the article's Creative Commons licence and your intended use is not permitted by statutory regulation or exceeds the permitted use, you will need to obtain permission directly from the copyright holder. To view a copy of this licence, visit http://creativecommons.org/licenses/by/4.0/.

\section{References}

Abudeif AM, Attia MM, Radwan AE (2016) New simulation technique to estimate the hydrocarbon type for the two untested members of Belayim Formation in the absence of pressure data, Badri Field, Gulf of Suez, Egypt. Arabian J Geosci 9(3):218

Asquith GB, Gibson CR (1982) Basic Well Log analysis for Geologists, vol 3. American Association of Petroleum Geologists, Oklahoma, p 216

Asquith GB, Krygowski D, Gibson CR (2004) Basic Well Log Analysis, vol 16. American association of petroleum geologists, Tulsa, OK

Attia MM, Abudeif AM, Radwan AE (2015) Petrophysical analysis and hydrocarbon potentialities of the untested Middle Miocene Sidri and Baba sandstone of Belayim formation, Badri field, Gulf 
of Suez, Egypt. J African Earth Sci 109:120-130. https://doi.org/ 10.1016/j.jafrearsci.2015.05.020

Bai Z, Tan M, Li G, Shi Y (2019) Analysis of low-resistivity oil pay and fluid typing method of chang 81 member, yanchang Formation in huanxian area, ordos basin, China. J Petrol Sci Eng 175:1099-1111

Coughlin RM, Bement WO. and Maloney WV (1993) Petroleum Geology of the Deltaic Sequence, Rio Del Rey Basin, offshore Cameroon, AAPG International Conference and Exhibition, the Hague, Netherlands 17-20.

Darling T (2005) Well logging and formation evaluation. Elsevier

Delalex J (2014) Diagraphie différée et interprétation, IFP Training, pp 148

Doust H, Omatsola E (1990) Divergent/passive margin basins. AAPG Memoire 48:239-248

Dumort PJ, (1968) Notice explicative sur la feuille de Douala-Ouest. Direction des Mines et de la Géologie du Cameroun, Yaoundé 1: 69

Kiki A, Kaki C and Almeida GA, (2018) Évaluation par les méthodes diagraphiques des caractéristiques des réservoirs gréseux de la formation albienne dans la partie offshore profond du bassin côtier béninois. Rev. Ramres 6 (1): 2424-7235

Koum S (2013) L'étude de la surrection de la partie sud de cette marge au plio-pleistocene à travers une double approche, géomorphologique a terre et stratigraphique en mer. DEA en géologie des bassins, université de douala 3-10.

Kumar R, Das B, Chatterjee R, Sain K (2016) A methodology of porosity estimation from inversion of post stack seismic data. J Nat Gas Sci Eng 28:356-364

Meunier, M (2011) Diagraphie différée, IFP Training, pp 134

Mvondo FO (2010) Surrection cénozoïque des marges passives de l'ouest d'Afrique a partir de deux exemples : plateau sud namibien, la marge nord camerounaise. Thèse de doctorat université de renne, Pp 359

Nair KM, Ramanathan RM, Ukpong EE (1981) Sedimentology and stratigraphy of Cretaceous carbonates and associated rocks of Calabar Flank. Nigeria Jour Min Geol 18(1):120-129

Nguene RR, Tamfu S, Loule JP And Ngassa C (1992) Paleoenvironment of the Douala/Kribi Campo Sub-basins in Cameroon, West Africa. Geologie Africaine; Colloque Geologic, pp 129-139

And NOA, Agbor JT (2016) Shallow marine cretaceous sequences and petroleum geology of the onshore portion Rio del Rey basin, Cameroon, Gulf of Guinea. J Mar Sci 6:177-192

Njoh OA, Nkeme UU (2008) Paleodepositional environments of some lower tertiary subsurface sediments in the Calabar, S. E. Nigeria. Glob J Geological Sci 7(1):1-6
Njoh OA, Petters SW, Akpan EB (2010) Trace fossils and foraminiferal evidence for basinal tectonics, Calabar Flank basin S.E. Nigeria. African Geosci Rev 7(4):233-242

Petters SW, Nyong EE, Akpan EB And Essien NU (1995) Lithostratigraphic Revision of the Calabar Flank. Thirty First Annual Conference, Nigerian Mining and Geoscience Society, pp 54.

Rabinovich PD, Labrecque J (1979) The Mesozoic South Atlantic Ocean and evolution of its continental margin. J Geophys Res 84:5973-6002

Radwan AE (2018) New petrophysical approach and study of the pore pressure and formation damage in Badri, Morgan and Sidki fields, Gulf of Suez Region Egypt. PhD Thesis. https://doi.org/10.13140/ RG.2.2.26651.82727

Saadu YK, Nwankwo CN (2017) Petrophysical evaluation and volumetric estimation within Central swamp depobelt, Niger Delta, using 3-D seismic and well logs. Egypt J Pet. https://doi.org/10. 1016/j.ejpe.2017.08.004

Schechter VS (2010) Crossplot, Porosity and Lithology. Formation evaluation. pete. p.32. internet source, universitylectures. http:// www.pe.tamu.edu/blasingame/data/z_zCourse_Archive/P663_ 10B/P663_Schechter_Notes/PETE_663_CROSSPLOT_B_DSS. pdf

Serra O, (1979) Diagraphies Différés base de l'interprétation. Mémoire1 Tome1. Services techniques Schlumberger, Paris, pp 631.

Societé National Des Hydrocarbures (SNH) (2005) Rapport sur la synthèse sur le Bassin du Rio Del Rey et sur le bassin de Douala/ Kribi-Campo.

Societé National Des Hydrocarbures (SNH), (2015) Blocks on offer in the Rio Del Rey basin, DKC and Mamfe basin 1-16.

Staffan K, Van Dyke J, Basick, V. and Sahay K, (2010) Open Hole Logging: Potential Gamma-Ray Interpretation Concerns. Oil and Gas Evaluation Report .

Upal S, Delwar H, Sakawat H, RahmanKamruzzaman JJ (2020) Geophysical characterization of the sangu gas field, offshore, bangladesh: constraints on reservoirs. J Pet Geol 43(4):363-382

Varhaug M (2016) Basic well Log Interpretation. Oilfield Rev 52-53

Publisher's Note Springer Nature remains neutral with regard to jurisdictional claims in published maps and institutional affiliations. 